Vol. 3, No. 1, pp. 1-9, 2022

\title{
Human Rights Violation in the Manifestation of Indonesia's Inefficacious Covid-19 Policies Towards the Lower Socio-Economic Class
}

\author{
Dellvin Sergio \\ Faculty of Law, Atma Jaya Catholic University, Jakarta, Indonesia \\ Corresponding author mail: dellvin.lie@gmail.com
}

\begin{abstract}
Indonesia's surging number of Covid-19 positive cases may be happening due to its own manifestation through implementing ineffective laws which then led to the resurgence of the policy crisis. Indonesia is deemed to have failed in handling the overwhelming pandemic. The imbalance of emergency fund allocation between the recovery of the economy and health sector also conveys Indonesia's top priority. Policies made by the state also prove its failure in accommodating vulnerable people especially those who live in poverty. The application of the top-down policy affects those with financial insecurity then also burdened by extraordinary crimes such as corruption of social assistance mid pandemic. To implement an adequate policy which can respect, protect, fulfill, it is important to address poverty affected by covid policies through the lens of human rights, whether it is violated or fulfilled. The use of recent studies, official data, laws, policies, and human rights approaches will help indicate how people living in poverty are still marginalized of their rights to adequate standards of living pre and midst pandemic. Moving forward, those who live in poverty must live free from discrimination and stereotypes such as lazy, unlucky, undeserving, etc. which contributes to the exclusion and exploitation of this vulnerable group. This research will seek poverty as a human rights issue, it will show how this vulnerable group has been the victim of injustice and demand accountability. Through proper analysis, these findings will also set out appropriate and applicable solutions for the well-being of this group mid and post pandemic. The main finding is there has been a violation of human rights as state fails to enact its obligations to fulfill, protect and respect the human rights of those living in poverty.
\end{abstract}

Keywords: Covid-19, Pandemic, Policies, Poverty, Human Rights, Corruption.

\section{Introduction}

The deadly virus made its first debut in Wuhan City, Hubei Province, China on 31 December 2019 (World Health Organization, 2020). The virus which was then identified as novel beta-coronavirus (2019-nCov), now globally known as Covid-19 presents an acute viral respiratory infection alongside diagnoses of pneumonia (Wu et al. 2020). Most Covid-19 patients reveal symptoms such as dry cough, sore throat, and fever. However, the virus does give several patients dire complications which include organ failure, septic shock, severe pneumonia, etc. (Sohrabi et al. $2020,71)$. On 31 January 2020, WHO announced the virus outbreak as a public health emergency of international concern (WHO, 2020b) then followed by a declaration of the virus as a global pandemic on 11 March 2020 (World Health Organization, 2020).

At the time of the earliest announcement made by WHO, Indonesia has yet to declare any positive cases from its citizens. Until the very first case of Covid-19 announced by the President himself, Joko Widodo in early March 2020, with two of its citizens being in contact with their Japanese acquaintances. The late notification is combined with serious and controversial statements made by government officials (Terawan Agus Putranto, Indonesia's Minister of Health). The announcement made by the President caused chaos within its society which is reflected through the action of panic buying, even though the government has notified citizens not to panic through national media outlets. With both late and controversial statements which trivialize the danger means of the virus indicates Indonesia's government wills in confronting this catastrophe. The inconsistency of information and decisions made by the 
government is evident by the lack of preparations in facing this pandemic, without a definite strategy and solutions in tracking and abating the spread of the virus (Ayuningtyas et al., 2020; Andriyani et al., 2021; Patria, 2021).

There is no doubt that this unforeseeable pandemic has brought immense calamity in every aspect of our lives, whether it is the recession of the economy or the changing of our social and cultural life. Amid a pandemic, it is an important note to keep our health sector afloat to face this pandemic. Indonesia has shown its prioritization of the economy before the health sector with imbalance of finance allocation. Last year, Indonesia's Central Government allocated IDR 450 trillion for both the recovery of the economy and health sector. However, the health sector has only received IDR 75 trillion different from the economy sector which received over IDR 150 trillion. These prioritizations do raise concerns of the public. Hence in the year of 2021, the Ministry of Finance has raised IDR 75 trillion to over IDR 193 trillion (Ministry of Finance, 2020).

Indonesia as a developing country, in which the economy and health sector are still in its frangible state, it is important to take immediate responses (OECD, 2020). The immediate responses must prioritize inclusiveness, especially those groups who are in the most vulnerable state in contracting the virus and those greatly impacted by the pandemic (Gupta et al., 2020; Aditantri et al., 2021). This vulnerable group is implied to those who suffer from poverty, those who rely on daily income to live such as informal workers which still take up $60 \%$ of the population in Indonesia (BPS, 2021). Whereas the inimical reality of those who live within or under the line of poverty must constantly face circumstances such as destitution, abhorrent abandonment, and lack of social protection. Programmes made by Indonesia to cover those who live in extreme poverty still lack in distributions and allocation in covering every layer of those who live in poverty (UNICEF, 2021). Also remembering most of its social programmes are abused by authority and power through acts such as corruption midst pandemic (Prakasa et al., 2021).

It is inevitable to say that the state and government did not violate or preclude the enjoyment of human rights, more specifically economic, social, and cultural rights of this vulnerable group. Noting Indonesia as one of the 170 countries who ratified the International Covenant of Economic, Social and Cultural Rights and are bound in following obligations within the covenant (Law No.11/2005). Therefore, this paper will seek the injustice from the lack of prioritization, policy making, transparency, accountability, and corruption through the lens of human rights. This paper also has the means to address poverty issues not as a charitable work but as the effect of the violation of certain human rights such as the rights to adequate living in conjunction with rights to health, education, food, economy, social, and cultural rights (Arifuzzaman et al., 2021; Windari \& Effendi, 2021). Reminding state its responsibility in upholding obligations to respect, protect and fulfill the rights of those vulnerable in this and post pandemic.

\section{Methodology}

This paper is a product of an analysis review on public policy, laws and decisions made by the government with proper human rights guidelines. Through the human rights guidelines, this will allow the use of legal arguments in line with international and national human rights standards, more specifically the International Covenant on Economy, Social and Cultural Rights. Arguments embedded within this paper are backed with official documentations such as official websites of the government, national media and existing research journals which provide both quantitative and qualitative data. Through the analysis this paper will be pointing out necessary actions and recommendations for new laws and policy which are in accordance with human rights norms. Human rights norms and guidelines will not only be the pillar of inclusivity for those living in extreme poverty but also having those responsible to be held accountable.

\section{Results and Discussion}

\subsection{Characterization of poverty in the eyes of human rights and its violation}

Lousie Arbour once said "Today, poverty prevails as the gravest human rights challenge in the world. Combating poverty, deprivation and exclusion is not a matter of charity, and it does not depend on how rich a country is. By tackling poverty as a matter of human rights obligation, the world will have a better chance of abolishing this scourge in our lifetime... Poverty eradication is an achievable goal." (Arbour, 2006)

Till this day, the characterization of poverty is still consistently stigmatized to those enduring it. Stigmatization which bears prejudices such as unlucky, lazy, undeserving and criminals. All of these contributes to social exclusion which deprived those who live in poverty of their most basic human rights inter alia, adequate standards of living, food, water, health, education, work, and freedom from discrimination, remembering that all of human rights are interdependence, interrelated and indivisible. Though with their suffering, the rights of these people are still denied within the border of their own homeland.

Through a human rights approach and after the 2006 celebration of International Human Rights Day, poverty is deemed not as a matter of charitable work but an obligation to be decimated. Therefore, this paper refuses the idea that poverty is inevitable and inclines to identify actions done by human, state, or corporations to seek justice. Through a thorough identification and investigation, human rights approaches will demand the highest ground of 
accountability from those who let poverty prevail within one's society. Indonesia's National Committee of Human Rights has also called for the action in applying the human rights approach in addressing Covid-19 issues.

The Center for Economic and Social Rights states that the definition of poverty itself should not only consist of those having "low income" but broaden to a perspective that manifests in different types of deprivation of basic needs stated above. The deprivation of those basic needs also manifested in a way that let the vulnerability of this group stand out, resulting in both exploitation and humiliation in the form of social exclusion, violence, lack of access to public services, etc.. One of the things needed to be addressed is the issue of social exclusion which spawns poverty. Social exclusion is usually determined by the extreme prejudice with means of discrimination being institutionalized within law, policies, and other governmental decisions (DFID, 2005). These exclusions are usually targeted to vulnerable minority groups inter alia, the poor, the disabled, women, children, etc. through the lack of awareness (DFID, 2005). The identification of those living in extreme poverty should not remain narrow but also concise of interrelation for e.g., women in poverty, people with disability in poverty, elderly in poverty, etc. The actions of exclusion further impacted the suppression of rights realization of this vulnerable group, as they lack the independent resources to fend themselves (Hinsch and Stepanians, 2005). DFID explained that social exclusion results in material insecurity culminating in low income, denied access to social programs such as health and education. This precludes opportunities to achieve social mobility which provoke the increase of people living in poverty.

The Centre of Economic and Social Rights made a clear legal distinction between the non-enjoyment and violation of Human Rights. Poverty itself cannot be a violation but it can be a violation when measured by failures to meet the human rights obligations. For example, when marginalized groups are incapable of accessing education due to being poor, the non-enjoyment of those rights to education are not fulfilled (Humanium, n.d.). However, action such as commission and omission done by the government or its failure in accommodating the prevention of poverty are the one to be constituted as a violation. Therefore, in constituting poverty as a violation to human rights, it is right to identify the existence of 1) What human rights obligation is violated which includes, inter alia obligations to protect, respect and fulfill. 2) The identification of a specific human right. 3) Types of duties the government needs to comply with the specific right. 4) Identify the actions done by government or non-state actors that do not fall under the obligations (CESR, 2009).

In addition to the guidelines delineated by the Centre of Economic and Social Rights, the Maastricht Guidelines on Violations of Economic, Social and Cultural Rights displayed the minimum core obligations and availability of resources. Minimum core obligation refers to ensuring state compliance in upholding the satisfaction of the most essential obligations of the rights. Therefore, state parties are obliged to take the most appropriate and comprehensive means in enacting the rights bound within the covenant (E/1991/23). Whereas availability of resources refers to the state's obligation to take the necessary steps in using the maximum of its available resources with the means to fulfill the minimum obligations (E/1991/23). With the established guidelines, this will help convey whether Indonesia's Covid-19 policies have violated or preclude the enjoyment of human rights of those who live in poverty amidst pandemics.

\subsection{Poverty in Indonesia and government's effort - rights to social security}

According to Indonesia's Central Bureau of Statistic, the number of those living in poverty has increased immensely from September 2019- September of 2020 due to the Covid-19 Pandemic. The latest data shows that the poverty number in both urban and rural areas made a jump, with poverty in urban areas escalating from $7.38 \%$ to 7.85 (Badan Pusat Statistik, 2021). Whereas the number of poverties in rural areas rose from $12.82 \%$ to $13.20 \%$. The increasing number of those living in poverty has also proven to escalate in the number of informal workers by February 2021, with $60 \%$ of the population working in the informal sector. Indonesia's Central Bureau of Statistic has also conveyed their concerns for those working in the informal sectors to be at most risk in facing the Covid-19 Pandemic (Badan Pusat Statistik, 2021). The discourse of those living in poverty is not only estimated by the increasing number of people living in poverty but also the level of monthly expenditure with the lowest sitting at IDR 168,000 - IDR 560,000 (US\$ 11,4 - US\$ 38) (Badan Pusat Statistik, 2020).

With the surging numbers of poverty identified by the Central Bureau of Statistic, the state cannot ignore those who already live or are about to live in poverty. United Nations High Commissioner of Human Rights, Michelle Bacahelet has stated that those who live in poverty are at high risk of detrimental effects of Covid-19 and are most disregarded. Therefore, Indonesia who is currently experiencing turbulence should consider what to prioritize, in this case those who are most vulnerable - The poor. During this pandemic, Indonesia's government has imposed several social safety nets to accommodate who live in poverty. The several social safety nets include Family Hope Program (PHK), staple food cards, pre-employment cards, electricity subsidies, credit payment relief for informal workers, additional market and logistical operations, cash assistance for micro, small, and medium-sized enterprises, wage subsidies for formal worker and village cash transfer program.

Whether in the face of a pandemic or not, social protections such as these safety nets must be a constant consideration for those who are marginalized in our society - social security is a permanent entitlement. This obligation is enshrined within Article 9 of the International Covenant on Economic, Social and Cultural Rights which ruled that states have the responsibility in meeting one of the core obligations in recognizing individual's rights to social security which includes social insurance. Indonesia's government has certainly shown an ounce of effort in 
assisting those who are vulnerable through the application of social safety networks. However, the obligation to use the maximum of their available resources is still to be questioned in this pandemic. The lack of prioritization towards those who live in poverty will be further elaborated in the next part of this paper. The importance of social security plays a big part in alleviation and reduction of poverty, it also prevents social exclusion and promotes social inclusiveness (E/C.12/GC/19).

A quantitative and qualitative research has been conducted by SMERU, offering us numbers and insights towards the quality of these social safety nets. The research concluded that social assistance given by the government is reaching most of the population but still is not fairly distributed towards all people in need even though, government has allocated a total of US $\$ 10.9$ billion to cover social protection. The lack of data awareness is shown with only those at the poorest household receiving assistance such as the Family Hope Programs. Indonesia's irregular update on data (population data) may also contribute to the unattainability of this social assistance. The data also shows that the distribution of accessing different types of assistance is imbalanced. With the issuance of other social assistance, majority of the people (72.6\%) thought that cash transfer programs to be most beneficial. However, one in three households in the bottom $20 \%$ did not receive any type of cash assistance. After looking through the data arranged by SMERU, the prioritization of those living in poverty still does not reach its maximum capabilities (UNICEF, 2021). More social assistance needs to be fairly distributed especially for lower income households with women, persons with disability, and elderly. Emphasizing on the prioritization of women in poverty who shoulders the burden of modern conjugal roles being both caregivers and breadwinner of a family. Thus, accessibility of this social protection to have enough coverage, ensure eligibility, affordability, participations and information, and physical access (E/C.12/GC/19).

Through the analysis of the data provided by SMERU, the attention for accessibility for social assistance is to be doubted. In the light of acknowledging that those living in poverty have lower literacy skills compared to those living in a higher-income household, the Special Rapporteur on Extreme Poverty and Human Rights concluded that most applications that authorized the distribution of social assistance are not provided in appropriate language - without complex procedures and jargons. Ergo, governments are encouraged to build a system which is convenient to accommodate those living in poverty. Government may also employ more civil service employees to assist those in accessing social assistance - promote and educate. With applicating more of an appropriate language and jargons, the accessibility and approachability for social assistance to be ameliorated especially for those who have a lower education stance - non-discrimination (Suryahadi et al., 2020).

With implementing a pro-poor policy that are in favor of those living in poverty, government could undertake an extensive improvement especially towards the previous "inevitably poor" mindset and deemed unrealistic to diminish. "Political will has sufficed when it comes to poverty alleviation and prevention" with the means to invest considerable resources to the public service and preserve employment. As the procedures commend that governments to use the maximum of its available resources to eradicate poverty and let social protections prevail in society - Article 9 of ICESCR. It is also worth to note that the social security rights are interrelated with other fundamental human rights enshrined within the covenant (E/C.12/GC/19).

\subsection{Indonesia's Inefficacious Policy: Lack of Prioritization and Participations}

The Covid-19 Pandemic is in no way a serendipitous event in our lifetime. However, The World Health Organization has declared twenty widespread diseases that have occurred in the last centuries (Pfefferbaum and North, 2020). The occurrence of both pandemic and epidemic, shows that this type of outbreak is indeed perennial. The perenniality of pandemic has compelled WHO in foreseeing such a breakout. Hence, WHO has created anticipatory guidelines regarding facing a pandemic. The measures to be taken highlighted the threat of the pandemic or epidemic, inter alia the discussion on outbreak control that cover both socio-economic and political determinants, modernization of traditional measures (quarantine, isolation, culling, etc.), auguring the political challenges, the interconnection with ecosystem and social habitats, the preparedness of society in engaging with the outbreak and lasty, the revisiting or adapting public health measures. The presence of these measures has showcased that WHO as an international organization is encouraging anticipatory measures to be taken by countries. Evoking that Indonesia has ratified one of WHO's mandates, the International Health Regulations (IHR) in 2005. The implementation of IHR 2005, has the regulatory measures to prevent and provide public health response of transactional diseases between countries enshrined in Article 4 of IHR.

Nationally, Indonesia has its own provision in anticipating calamity such as the Covid-19 Pandemic with implementing laws. Mainly, Law Number 4 of 1984 regarding Infectious Diseases Epidemics and Law Number 24 of 2007 concerning Disaster Management. Ayuningtiyas et al, asserted that this existing law has proven its inadequacy in performing its purpose in tackling the Covid-19 pandemic. The laws that have failed in meeting its expectation contributes to the emergence of new government regulations inter alia, two Presidential regulations, Four Presidential Decrees, one Presidential Directives and one Government Regulation in lieu of law (Roziqin et al., 2021). By the end of March 2020, Government has issued a total of 11 regulations that range from the Ministry of Health, National Disaster Management Agency (BNPB), Ministry of Finance, National Police, Ministry of Communication and Information, Village, Regional disadvantage and Transmigration Minister and President of Indonesia (Djalante et al., 
2021). However, since last year Indonesia has issued numerous public information, policy, regulations, decrees, etc. that may cause the overlapping of information, that information can be accessed through a constantly updated website. With the intersecting regulations, confusion and uncertainty is undeniable, especially among those who lack in understanding the seriousness of the information published - lower-income households have lower levels of vocabulary, communication skills, knowledge of numbers, ability to concentrate, etc. (Ferguson et al., 2007).

One of the most known policies applied during the pandemic is Large-scale Social Distancing or also known as Large-Scale Social Restrictions (PSBB). This policy is embedded in Government Decree Number 20 of 2020 concerning Large-scale Social Distancing, implemented last year on the 31st of March 2020. The Policy has the means to limit and regulate the movement in regional areas with positive cases and to suppress the spread of the virus. The measure taken by the government by implementing the PSBB policy certainly constraints the movement of socioeconomic activities, especially for those who are working in informal sectors (Prawoto et al., 2020). The long-term enforcement of the PSBB policy sacrifices the livelihood of those living in poverty, which rely on daily income to fill the needs on their table - food, water, electricity, etc. With those forced out of employment $(9,77$ million by December 2020) in regard to stopping the spread of this virus, the policy has shown its ineffectiveness in performing its task. Researcher LSI Denny JA's has proven that the policy has not been able to subdue the spreading of the virus after 3 months of implementation.

One of the defects from this policy is the lack of prioritization towards vulnerable groups. The application of the PSBB policy done by the government, both central and regional, has disregarded the pre-existence of social inequalities. Therefore, the policy implies lack of prioritization and promotes social exclusion of those living in poverty during pandemic. This pre-existing social inequality refers to class and genders (Bajos et al., 2021). Affirming that this policy is only applicable for those endued with privileges - higher-income class. It seems like Indonesia's government has omitted the differences in living conditions between its citizens, some may live in a safegated community, but some may live in a cluttered space.

To be more precise, here are some antecedents characterization of the living conditions of those living in extreme poverty: 1) Accumulated in rural areas; 2) those at risk of climate change; 3) Low education level; 4) lack of resources; 5) majority specialized in Agriculture; 6) bigger family size; 7) low income; 8) suffers from food insecurity and 9) lack of sanitation which contributes to health (Murali and Oyebode, 2004). Swastika and Supriyatna (2008) cites the dimensions of those living in poverty from Sudaryanto and Rusastra, which includes: 1) inability to meet basic needs inter alia, food, shelter, sanitation, education, clean water etc.; 2) preclude from doing capital accumulations; 3) Vulnerable to external majeures inter alia, disease, natural/non-natural disasters, etc.; 4) social exclusions; 5) lack of working opportunities; 6) the disabled, the elderly, and the Youngs.

Through looking over the implementation of the PSBB policy, those who live in poverty have very little to no measures that let them abide by the rules. Yet, they are still legally bound to comply to the extent that they also need to suffer from sanctions if those policies are to be contravened. This certainly shows the disproportionate nature of the policy implied with the capabilities of those living in poverty. The main lack of capabilities that hinder those living in poverty to comply includes:

1. Lack of Space and access (Friesen and Plez, 2020)

People living in poverty tend to live in clustered spaces such as slums or also known as informal settlements. The living conditions provided in this precarious household exposed vulnerable people to infectious diseases such as the Covid-19 due to less hygiene and access to sanitation. Therefore, the agglomerations of people living per dwelling is impossible to implement social distancing (PSBB). These living conditions also engender the health and well-being of the people, causing the deprivations to the enjoyment of the right to adequate living standards. When the lack of space is suffered by people living in urban areas, the majority of those living in poverty reside in rural areas. The occupied rural areas by those living in poverty may have an adversity in accessing social assistance.

2. Impeding on social activities (Gupta et al., 2021)

The PSBB policy also hinders people living in poverty to shift from offline to online setup with experiencing loss - in money and energy. The shift to online precludes the continuation of activities such as education and work. This stay at home and social distance policy are only applicable to higher-income households, as they have the disposable income to spend on internet or other ICT facilities. Though, it's important to mention that the government has subsidies and given students free internet quota during the first several months of the pandemic through the Ministry of Education and Culture.

Upon all the pre-exquisite living conditions mentioned above which preclude the enjoyment of basic standards of living, governments have downright looked upon the threats people living in poverty have to face daily even before the pandemic. Thus, those who live in poverty whilst having precarious employment and heavily rely on daily income, cannot necessarily comply with the PSBB policy (Eraso and Hills, 2021). The assumptions taken by the government that every citizen can comply with this policy is discriminatory towards the poor - classist.

The paucity of prioritization in policy making done by the government towards people living in poverty is through the manifestation of lack of participation of this vulnerable group. The lack of participation is evident by those sitting on the chair of legislation; they have little to no experience of poverty but are entitled in making policy that might have detrimental consequences to those living in poverty (Harris, 2005). Therefore, it is salient to make sure people living in poverty are part-taking in every step of decision making, especially decisions that influence their interests. 
The Report of the Special Rapporteur on Extreme Poverty and Human Rights by Sepúlveda Carmona (2013) has put together comprehensive guidelines and recommendations on the participation of the poor through a human rights perspective. The discussion of the lack of participation in Indonesia's policymaking will follow guidelines from this special rapporteur. Studies done by Amaliah et al. (2014) found that most people in poverty do not necessarily have the political awareness on what they advocate, mostly people living in poverty manipulated in supporting political representatives but then only to be neglected. It has been identified the obstacles that are restraining those living in poverty from engaging. These obstacles include, discrimination, stigma, disempowermnet, lack of income, mistrust of authorities which inherently rooted in the economic, social, structural, legal systems (A/HRC/23/36). Therefore, Indonesia's government has to take into account these obstacles in promoting participation with utmost equality even among genders representations from the community. Participation also encourages persecution against oppression and abuse of power. Through effective participation, people living in poverty can wield their selfdetermination, agency and autonomy to confront inequality and discrimination (A/HRC/23/36).

Participation here is strongly associated as a fundamental human right which intercorrelated with other rights (Interdependent and indivisible principles) inter alia, freedom of expression, freedom of assembly, freedom of association, right to seek, receive and impart information, right to education (A/HRC/23/36). All of these rights are enshrined within international human rights law that includes Universal Declaration of Human Rights (UDHR), International Covenant on Civil and Political Rights, International Covenant on Economic, Social and Cultural Rights, Convention on the Rights of Children, Convention on the Elimination of all Forms of Discrimination Against Woman and Convention on the Rights of Person with Disabilities. Noting that states are bound to meet these positive obligations to ensure that every citizen including minority have the chance to partake in public affairs and any decision making. Recalling Indonesia as one of the countries to ratify all laws above; therefore, Indonesia is legally bound and has to meet every core obligation which is to respect, protect and fulfill these rights or to be held accountable. Thus, Indonesia's top-down hierarchical policy is not in-line with the principle of participations which further exclusiveness $(\mathrm{A} / 63 / 272)$.

\subsection{Addressing Corruption in Indonesia as a violation of human rights midst pandemic}

Mentioning Indonesia and corruption together is no stranger, as Indonesia was ranked at 89th for worst corruption case among 180 other countries. The extraordinary crimes still proudly flaunted itself amidst pandemic. Hence, The World Bank (2020) suggests the importance of curbing corruption in this pandemic. Corruption is deemed as one of the deadliest diseases to exist within our democratic society, it even prevails at the worst time threatening the livelihood of its citizens - The vulnerable. This paper is set to seek corruption as a violation of human rights issues as it contradicts the supposed positive duty of a state - to fulfill. Reaffirming that states must meet the minimum core obligations in using its maximum of available resources; therefore, arguments such as "lack of resources" is not credible.

"Even prevails at the worst time" refers to the menace of Covid-19 to the public. Even so, this does not stop public officials from taking advantage of the allocation of finance distributed during the pandemic, especially the widespread corruption of social assistance. The corruption happened on the early stage of the pandemic that consisted of social assistance such as social packages valued over IDR 5,9 trillion. The corruption on social assistance is done through acts of commission and omission (E/C.12/GC/19): respectively, commissioned by former Ministry of Social Affairs, Juliari Batubara and omission by Matheus Joko Santoso, Adi Wahyono, Ardian I M, Harry Sidabuke. Even preexisting corruption law Number 20 of 2001, has failed to act as a deterrent in preventing this extraordinary crime. Even though, stated on Article 2 (2) Law Number 10 of 2001 amendments of Law Number 31 of 1999 concerning corruption; corruption done in time of emergency constitute the possibility of death penalty. However, Juliari Batubara (former Ministry of Social Affairs) only to be sentenced to 12 years in prison. Not only the existing law fails in preventing the acts midst pandemic, but the accountability burdened by public officials are still disproportionate. The disproportionate sentencing of this crime is due to the indirect link of human rights violations in precluding those who need and rely on social assistance to survive daily. Thus, threatening the life of those living in poverty. The presence of corruption of social assistance during covid-19 pandemic also constitutes a direct violation to human rights done by state; state has failed in preventing such crimes with implementing ineffective law which violates obligations to fulfill and protect. The rights of those living in poverty inter alia, rights to social security, rights to health and rights to adequate standards of living are infringed.

Corruption done by public officials also violates the principle of non-discrimination and equality. The act itself upon social assistance is a distorts that contributes to discrimination as a purpose and effects. Those living in poverty are the most vulnerable groups and set forth to rely on this social protection. However, people living in poverty rarely seek legal remedies as they are often difficult to reach and reluctant to voice their concerns (principle of accessibility). Therefore, accessibility to fulfill is also violated as the state fails in preventing such interference towards obtaining corrupted assistance (E/C.12/GC/19). The violation to fulfill (accessibility) is also evident with research done by SMERU, which concluded that social assistance has not reached all layers of those living in poverty, not an effect of lack of resources but effect by acts of corruption. 
The acts of corruption itself are water-down, from those sitting in as national government to provincial administration, then towards directors or managers of institutions. The social programmes known as bansos (bantuan sosial) which mostly consist of food, embezzlement and frauds done by public officials have affected food safety and dietary needs of those suffering from food insecurity during this pandemic. Nevertheless, the government and state have violated obligations to use the maximum of its available resources enshrined in Article 2(1) in ICESCR. Since the act of corruption itself has been done, Indonesia now has the obligation to ensure effective remedies towards those living in poverty. Whether those remedies come in the form of legal, administrative, judiciary or judicial, these measures must be taken in a way to their most effectiveness. Therefore, victims (people living in poverty) are fully entitled to acquiring the most adequate reparation such as compensation, satisfaction and guarantees of non-repetition. These remedies are obtainable through effective incorporations of both national and international instruments and measures in assuring the utmost realization of violations,

\section{Conclusion}

After the thorough research and analysis done in current emerging public policy, laws, and states effort in accommodating those living in poverty during the pandemic. It is concluded that states have ignored the possibility of using human rights approaches in both making and implementing policies regarding the protection of those vulnerable in the pandemic. The ignorance accumulated in the violations of human rights of people living in poverty, these rights include the right to social security, rights to adequate standards of living and rights to health. The violations prevail as states fail to take anticipatory measures in preventing the exclusiveness of policy and crimes such as corruption. Violations will constantly occur if states still consider that the eradication of poverty is inevitable. When someone cannot benefit from a system that inherently should cater to those vulnerable, it is indeed discriminatory.

The importance to note that those living in poverty should not be seen as a charitable act but relates to the violation of fundamental human rights must be in constant consideration of the states. Keeping in mind that Indonesia as a state has ratified human rights treaties and promised to uphold those rights enshrined within the covenant. States, therefore, have the utmost responsibility in meeting all core obligations - to protect, respect and fulfill the rights affected by the pandemic. Showing great inclusiveness is a great first step in fulfilling these obligations through the encouragement of participation, transparency, and accountability. Through fulfilling the obligations so that people living in poverty can access their rights to social protection is also one way to keep the economy afloat during this hard time. The implementation of policies during covid-19 pandemic should always be in reckon with constitutions and other human rights treaties.

Even after careful research and analyzing, the authors of this paper, recognized and acknowledged that upholding human rights in every aspect of our life is not an easy task and needed to be executed with the most careful and considerate measures. It may seem that poverty is inexorable and unattainable, that only exists in an idealistic world, but realizing that states have unmeasurable possibilities to prevent such violation through active and effective collaborations with institutions and its citizens. After a heavy lesson given by going through such calamities, Indonesia must anticipate in guaranteeing the non-repetition of the same and other violations of human rights of its citizens moving forwards.

\section{Acknowledgement}

The author would send his greatest appreciation towards Ms. Asmin Fransiska as author's Lecture on Human Rights class and Dean of the Faculty of Law in Atma Jaya Catholic University for the encouragement and guidance of this paper.

\section{References}

Aditantri, R., Mahliza, F., \& Wibisono, A. D. (2021). Urban Planning and E-Commerce: Understanding the Impact During Pandemic Covid-19 in Jakarta. International Journal of Business, Economics, and Social Development, 2(3), $135-142$.

Amaliah, A.N., Hasanuddin, M., \& Said, M. (2015), Participation of People in Poverty of Makassar on the 2014 Election of the President and Vice President, Otoritas Jurnal Ilmu Pemerintah, 5(1), 16-28.

Andriyani, D., Nailufar, F., Yurina, Y., Ratna, R., \& Rahmah, M. (2021). Analyzing the Sustainability of Micro, Small and Medium Enterprises during Covid-19 Pandemic in Bireuen Regency, Indonesia. International Journal of Business, Economics, and Social Development, 2(3), 119-126.

Arbour, L., (2006a), "Human Rights Day Statements", Retrieved from https://www.ohchr.org/EN/NewsEvents/HRDay2006/ Pages/statements.aspx 
Arifuzzaman, M., Rafee, F. E. R., \& Islam, M. J. (2021). Exploration of poverty and human rights violation: a legal analysis. Asian J. Soc. Sci. Leg. Stud, 3(1), 10-22.

Ayuningtyas, D., Haq, H. U., Utami, R. R. M., \& Susilia, S. (2020), Requestioning the Indonesia Government's Public Policy response to the Covid-19 Pandemic: Black Box Analysis for the Period of January-July 2020, Frontiers in Public Health, 9 , 454.

Badan Pusat Statistik (2020), "Profil Kemiskinan di Indonesia Maret 2020” (Indonesia’s Poverty Profile in March 2020), Berita Resmi Statistik, pp. 7-8, Retrieved from https:/www.bps.go.id/pressrelease/2020/07/15/1744/persentase-penduduk-miskinmaret-2020-naik-menjadi-9-78-persen.html

Badan Pusat Statistik (BPS) (2021), "Berapa Jumlah Pekerja Informal Pada Bulan Februari 2020” (Numbers of Informal Workers by February 2021), Retrieved from https://databoks.katadata.co.id/datapublish/2021/05/07/berapa-jumlah-pekerja-informalpada-februari-2021

Bajos, N., Jusot, F., Pailhé, A., Spire, A., Martin, C., Meyer, L., ... \& Carrat, F. (2021). When lockdown policies amplify social inequalities in COVID-19 infections: evidence from a cross-sectional population-based survey in France. BMC public health, 21(1), 1-10.

Centre for Economic and Social rights (2009), "Human rights and Poverty: Is poverty a violation of human rights", Human Rights Insights, (1), pp. 1-2, Retrieved from https://www.cesr.org/poverty-and-human-rights-poverty-violation-human-rights

Department for International Development (DFID) (2005), “Reducing Poverty by Tackling Social Exclusion”, pp.3-5, Retrieved from https://www2.ohchr.org/english/issues/development/docs/socialexclusion.pdf

Djalante, R., Lassa, J., Setiamarga, D., Sudjatma, A., Indrawan, M., Haryanto, B., ... \& Warsilah, H. (2020). Review and analysis of current responses to COVID-19 in Indonesia: Period of January to March 2020. Progress in Disaster Science, 6, 100091.

Ferguson, H. B., Bovaird, S., \& Mueller, M. P. (2007). The impact of poverty on educational outcomes for children. Paediatrics \& child health, 12(8), 701-706.

Friesen, J., \& Pelz, P. F. (2020). COVID-19 and Slums: A Pandemic Highlights Gaps in Knowledge About Urban Poverty. JMIR Public Health and Surveillance, 6(3), e19578.

Eraso, Y. \& Hills, S., (2021), Intentional and unintentional non-adherence to social distancing during Covid-19: A mixedmethods analysis, PLOS ONE, 16,(2), 0256495.

Gupta, J., Bavinck, M., Ros-Tonen, M., Asubonteng, K., Bosch, H., Ewijk, E. V., Hordijk, M., Leymseele, Y. V., Cardozo, M. L., Miedema, E., Pouw, N., rammelt, C., Scholtens, J., Vegelin, C., \& Verrest, H., (2021), "Covid-19, poverty and inclusive development", World Development, 145, 105527

Hinsch, W., \& Stepanians, M. (2005). Severe Poverty as a Human Rights Violation-weak and strong. In Real World Justice (pp. 295-315). Springer, Dordrecht.

Harriss, J. (2005). Political participation, representation and the urban poor: Findings from research in Delhi. Economic and Political Weekly, 40(11), 1041-1054.

Ministry of Health Republic of Indonesia (2011), IHR Cegah Penyebaran penyakit Antar Negara" (IHR Prevents the Spreading between Countries), Retrieved from https://www.kemkes.go.id/article/print/1379/ihr-cegah-penyebaran-penyakit-antarnegara.html

Ministry of Finance (2021), "Pemerintah Menambah Anggaran Kesehatan MenjadiRp193,93 Triliun untuk Penanganan Pandemi Covid-19”, (Government Allocate more Financial Allocation to Health Sector, IDR193,93 Trillion to handle Covid-19 Pandemic). Retrived from https://www.kemenkeu.go.id/publikasi/berita/pemerintah-menambah-anggaran-kesehatanmenjadi-rp193-93-triliun-untuk-penanganan-pandemi-covid-19/

Murali, V., \& Oyebode, F. (2004). Poverty, social inequality and mental health. Advances in psychiatric treatment, 10(3), 216224.

National Committee of Human Rights, "Law No.11 of 2005 concerning International Covenantof Economic, Social and Cultural Rights", Retrieved from https://www.komnasham.go.id/files/1475231620-uu-no-11-tahun-2005-tentang-pengesahan\$PXTXO.pdf 
Organisation for Economic Co-operation and development (OECD) (2020), "Strengtheninghealth system during a pandemic: The role of development finance", Retrieved from https://read.oecd-ilibrary.org/view/?ref=134_134620xueji119ph\&title=Strengthening-health-systems-during-a\%20pandemic-The-role-of-development-finance $\&$ ga=2.2455445 83.221594794.1629653894-66263311.1629653894

Patria, L. (2021). Fuzzy Time Series Application in Predicting the Number of Confirmation Cases of Covid-19 Patients in Indonesia. International Journal of Quantitative Research and Modeling, 2(4), 193-200.

Pfefferbaum, B., \& North, C. S. (2020). Mental health and the Covid-19 pandemic. New England Journal of Medicine, 383(6), 510-512.

Prakasa, S. U. W., Hariri, A., Nuriyah, I., Asis, A., \& Salam, I. (2021). Social aid of Covid-19 corruption: strategy and mitigation policy of Muhammadiyah East Java. Legality: Jurnal Ilmiah Hukum, 29(1), 27-45.

Prawoto, N., Purnomo, E. P., \& Zhara, A. A., (2020), The Impacts of Covid-19 Pandemic on Socio-Economic Mobility in Indonesia." International Journal of Economic and Business Administration, 8(3), 57-71.

Roziqin, A., Mas'udi, S.Y.F., Sihidi, I.T., (2021), “An analysis of Indonesian government policies against Covid-19”, Public Administration and Policy, 24(1), 92-107.

Sepúlveda Carmona, M. (2013). Report of the Special Rapporteur on Extreme Poverty and Human Rights: Unpaid Care Work and Women's Human Rights. Available at https://ssrn.com/abstract=2437791

ohrabi, C., Alsafi, Z., O’Neill, N., Khan, M., Kerwan, A., Al-Jabir, A., Iosifidis, C., \& Agha, R. (2020), World health Organization declares global emergency: A review of the 2019 novel coronavirus (COVID-19), International Journal Surgery,. 76, 71-76.

Swastika, D. K. S., \& Supriyatna, Y. (2008). The characteristics of poverty and its alleviation in Indonesia. Forum Penelitian Agro Ekonomi, 26(2), No. 2, pp. 103-115).

Suryahadi, A., Al Izzati, R., \& Suryadarma, D. (2020). Estimating the impact of covid-19 on poverty in Indonesia. Bulletin of Indonesian Economic Studies, 56(2), 175-192.

UNICEF, UNDP, Prospera, SMERU (2021), “Analysis of the Social and Economic Impacts of Covid-19 on Household and Strategic Policy Recommendations for Indonesia, Jakarta" pp.6-27, Retrieved from https://smeru.or.id/en/content/executive-summary-report-social-and-economic-impacts-covid-19-households-and-strategic

Windari, R., \& Effendi, T. (2021). Child Rights and Human Security: Promoting Child Protection at the Tourist Attractions on Madura. International Journal of Business, Economics, and Social Development, 2(4), 162-170.

World Health Organization (WHO) (2020). Archived: WHO Timeline - Covid-19, Retrieved from https://www.who.int/news/item/ 27-04-2020-who-timeline---covid-19

World Health Organization (WHO) (2015), “Anticipating Emerging Infectious Disease Epidemics”, WHO Informal Consultation, p.45, Retrieved from https://apps.who.int/iris/bitstream/handle/10665/252646/WHO-OHE-PED-2016.2-eng.pdf

Wu, Y., Chen, C., \& Chan, Y. (2020), The outbreak of Covid-19: An overview, Journal of the Chinese Medical Association, 83(3), 217-219. 